\title{
Application of stool-PCR for the diagnosis of Helicobacter pylori from stool in Nigeria- a pilot study
}

\author{
Stella I Smith ${ }^{*}$, Muinah A Fowora ${ }^{1}$, Olufunmilayo A Lesi ${ }^{2}$, Elizabeth Agbebaku ${ }^{3}$, Peter Odeigah ${ }^{3}$, \\ Fatimah B Abdulkareem ${ }^{4}$, Charles A Onyekwere ${ }^{5}$, Chimere A Agomo ${ }^{6}$ and Monica Contreras ${ }^{7}$
}

\begin{abstract}
There are various methods for detection of Helicobacter pylori and the gold standard for non-invasive detection is the urea breath test (UBT). The aim of the study is therefore to detect $\mathrm{H}$. pylori from the stool of patients with dyspepsia by PCR and compare results obtained with UBT. A total of 97 stool samples from patients presenting with dyspeptic symptoms in Lagos University Teaching Hospital (LUTH) were screened for urea breath test (UBT) and the presence of $H$. pylori DNA using stool-PCR. Out of 97 stool samples analysed, 38 (39.2\%) were positive for Helicobacter spp. and 20 (20.6\%) positive for H. pylori by PCR, through amplification of 165 rRNA and glmM genes respectively. Of the 20 positive by $\mathrm{g} / \mathrm{mM}$ gene, the cagA gene was detected in 8 (40\%) samples, while 47 (48.5\%) out of 97 stool samples were positive for $\mathrm{H}$. pylori by UBT. The sensitivity and specificity of the $\mathrm{g} / \mathrm{mM}$ gene compared with UBT as the gold standard is $42.6 \%$ and $100 \%$ respectively. The positive predictive value (PPV) was $100 \%$ while the negative predictive value (NPV) was $60 \%$.The method may be useful for detecting H. pylori from stool amongst children especially where most hospitals lack endoscope for children although the method is expensive.
\end{abstract}

Keywords: UBT, Stool-PCR, Helicobacter pylori, Nigeria

\section{Introduction}

Helicobacter pylori is the causative agent of gastritis, peptic ulcer disease (PUD), MALT lymphoma and a risk factor in the development of gastric cancer (Blaser and Berg 2001). It has also been classified as a class I carcinogen by the International Agency for Research on Cancer (IARC) Monogr Eval Carcinog Risks Hum 1994 (an arm of WHO) in 1994. The mode of transmission still unknown, although epidemiologic studies suggest close person to person contact, intrafamilial spread. There is still uncertainty whether transmission occurs primarily through faecal-oral or gastric-oral route (Covacci et al., 1999). There are various tests for $H$. pylori diagnoses broadly categorized into two: invasive and non-invasive (Mégraud and Lehours 2007). Invasive methods require endoscopy while the non-invasive

\footnotetext{
* Correspondence: stellaismith@yahoo.com

${ }^{1}$ Molecular Biology and Biotechnology Division, Nigerian Institute of Medical Research, 6 Edmond Crescent, Yaba, PMB 2013, Lagos, Nigeria Full list of author information is available at the end of the article
}

methods do not. The invasive methods include culture (which is the gold standard), Rapid urease tests (RUT), histology, direct gram stain, PCR based methods and fluorescence in situ hybridization (FISH). The noninvasive methods include serology (which does not measure active infection), urea breath tests (UBT) (both ${ }^{13} \mathrm{C}$ and ${ }^{14} \mathrm{C}$, gold standard, which is an expensive test and cannot be available in routine clinical laboratories), Helicobacter pylori stool antigen tests (HpSA) (Mégraud and Lehours 2007).

Helicobacter pylori can be detected in stool specimens either by culture (difficult due to diverse microorganisms in the stool and fastidious nature of $H$. pylori), HpSA (discrepancies also occur from one geographical area to the other) and stool-PCR (with success rates of $25 \%-$ $100 \%)$. Generally, the differences in detection rate of $H$. pylori in stool is due to $H$. pylori degradation in the gastrointestinal tract and/or presence of inhibitors such as complex polysaccharides and also its presence in low concentration in stools (Kabir 2001).

\section{Springer}

(c) 2012 Smith et al.; licensee Springer. This is an Open Access article distributed under the terms of the Creative Commons Attribution License (http://creativecommons.org/licenses/by/2.0), which permits unrestricted use, distribution, and reproduction in any medium, provided the original work is properly cited. 
Many PCR methods have been developed to detect the organism directly in different clinical specimens. Various authors have reported on the use of stool-PCR for diagnosis of H. pylori (Şen et al. 2005; Hirai et al. 2009; Aktepe et al. 2011). The sensitivity with this method in recent times has varied from 21\%-65.22\% (Aktepe et al. 2011; Şen et al. 2005). However non-invasive methods that give accurate results are sought after. The study is therefore aimed at detecting $H$. pylori in stools of patients with dyspepsia using stool-PCR.

\section{Materials and methods}

Study period: August 2009-April 2010.

Ethical approval was obtained from NIMR-IRB, while informed consent was obtained from patients before stool samples were taken.

Inclusion Criteria: patients not on antibiotics or PPI's/histamine- 2- receptor blockers at least a month before the study as well as presenting with dyspepsia symptoms.

Exclusion Criteria: those currently on antibiotics and or PPI's/histamine 2 receptor blockers.

\section{Clinical samples}

Sampling method: Convenient sampling. Stool samples from 97 dyspeptic patients at the LUTH were used for this study. The stool samples were collected using sterile toothpicks into eppendorf tubes containing $700 \mu \mathrm{l}$ absolute ethanol at room temperature. The samples was considered H. pylori- positive when $\operatorname{glm} M$ gene or both genes $(\operatorname{glm} M$ and $\operatorname{cagA}$ ) were detected by PCR, and the results compared with those from UBT as the gold standard and confirmatory test.

\section{UBT}

To screen for UBT, $H$. pylori testing was performed using a validated Heliprobe system (Noster AB Sweden). The heliprobe UBT is a ${ }^{14} \mathrm{C}$-based urea breath test for the detection of $H$. pylori infection. It comprises the Helicap TM capsule which contains the ${ }^{14} \mathrm{C}$-labelled urea which is swallowed and metabolized to carbon dioxide and ammonia by the urease enzyme produced by H. pylori. Labeled ${ }^{14} \mathrm{C}$ exhaled in the breath is captured by a breathcard and analysed by the automatic heliprobe analyser. Levels above 50 counts/min were considered positive of $H$. pylori infection.

\section{Stool-PCR}

16SrRNA gene (399 bp)

Briefly, DNA from the stool samples were purified using the QIAamp ${ }^{\circledR}$ DNA Stool Mini kit (Hilden, Germany) containing an inhibitEX (removes all DNA damaging substances and PCR inhibitors in stool), and detected using a PCR assay targeting a $399 \mathrm{bp}$ fragment of the
16S rRNA gene of Helicobacter spp. with two specific primers, HeliF (AAC GAT GAA GCT TCT AGC TTG CTA G) and HeliR (GTG CTT ATT CST NAG ATA CCG TCA T) (Germani et al. 1997). PCR was performed using the Ready To-Go PCR beads kit by GE Healthcare (Buckinghamshire, UK). Amplification was carried out in an Eppendorf Mastercycler gradient (Hamburg, Germany) using the following cycling parameters: An initial denaturation at $94^{\circ} \mathrm{C}$ for $5 \mathrm{~min}$ and 35 cycles of $94^{\circ} \mathrm{C}$ for $30 \mathrm{~s}, 56^{\circ} \mathrm{C}$ for $1 \mathrm{~min}$ and $72^{\circ} \mathrm{C}$ for $1 \mathrm{~min}$. This was followed by a final extension of $72^{\circ} \mathrm{C}$ for $10 \mathrm{~min}$.

The PCR product was separated on a 2\% Agarose gel and 50 bp ladder was used as DNA molecular weight standard.

\section{cagA gene (128 bp)}

PCR amplification using this primer was carried out using the primer set cagA-F : $5^{\prime}$-ATAATGCTAAATTA GACAACTTGAGCGA- $3^{\prime}$ and $5^{\prime}$-AGAAACAAAAGCA ATACGATCATTC-3' Rugge et al. (1999). The $25 \mu \mathrm{l}$ reaction mixture consisted of x1 PCR buffer, $1.5 \mathrm{mM}$ Magnesium Chloride, $200 \mu \mathrm{M}$ of each dNTP, 20pmol of each primer and $1 \mathrm{U}$ Taq DNA polymerase (Promega).

Amplification was carried out in an Eppendorf Mastercycler gradient using the following cycling parameters: an initial denaturation at $94^{\circ} \mathrm{C}$ for 5 min and 40 cycles of $94^{\circ} \mathrm{C}$ for $1 \mathrm{~min}, 54^{\circ} \mathrm{C}$ for $1 \mathrm{~min}$ and $72^{\circ} \mathrm{C}$ for $1 \mathrm{~min}$. This was followed by a final extension of $72^{\circ} \mathrm{C}$ for $5 \mathrm{~min}$. The PCR product was separated on a $2 \%$ Agarose gel and 50 bp ladder was used as DNA molecular weight standard.

\section{glmM gene (294 bp)}

The following primers were used: $\mathrm{F}$ : 5'-GGATAAGCTTTTAGGGGTGTTAGGGG-3' $(738-763)$ and R : 5'-GCTTACTTTCTAACACTAACGCGC-3' (1010-1033) Kansau et al. (1996). The $25 \mu \mathrm{l}$ reaction mixture consisted of x1 PCR buffer, $1.5 \mathrm{mM}$ Magnesium Chloride, $200 \mu \mathrm{M}$ of each dNTP, 20pmol of each primer and $1 \mathrm{U}$ Taq DNA polymerase (Promega).

The following were the conditions for amplification: one cycle of denaturation at $94^{\circ} \mathrm{C} \times 5 \mathrm{~min} ; 35$ cycles at $94^{\circ} \mathrm{C} \times 1 \mathrm{~min}$, annealing at $56^{\circ} \mathrm{C} \times 1 \mathrm{~min}$, and elongation at $72^{\circ} \mathrm{C} \times 2 \mathrm{~min}$, followed by a final elongation step by 1 cycle at $72^{\circ} \mathrm{C} \times 7 \mathrm{~min} .15^{\circ} \mathrm{C}$ and amplification was carried out in an Eppendorf Master cycler gradient (Hamburg). The PCR product was separated on a $2 \%$ Agarose gel and $50 \mathrm{bp}$ ladder was used as DNA molecular weight standard.

Sensitivity of the primers was determined by testing other bacterial strains from related genus e.g. Salmonella Typhimurium and E. coli. The results of the $g \operatorname{lmM}$ gene was compared with the gold standard (UBT) using the 
positive and negative predictive values and also the sensitivity and specificity.

The $g \operatorname{lm} \mathrm{M}$ and $c a g \mathrm{~A}$ genes are genes commonly used for the diagnosis of $H$. pylori directly from biopsy specimens as well as isolates and was therefore adapted for use for stool PCR in this study.

\section{Results}

None of the Salmonella Typhimurium or E. coli amplified with the set of specific primers for 16S rRNA and $\operatorname{glm} M$ genes.

Out of 97 stool samples analysed, Helicobacter spp. and H. pylori DNA were detected in 38 (39.2\%) and 20 (20.6\%) by $16 \mathrm{~S}$ rRNA and $g l m \mathrm{M}$ genes respectively. The detection of $\operatorname{cagA}$ positivity by PCR was observed in 8 out of 20 (40\%) samples positive for $g l m \mathrm{M}$ gene whereas 47 out of 97 (48.5\%) samples were positive for $H$. pylori by UBT (Table 1). Those simultaneously positive for stool-PCR ( $g \operatorname{lm} M$ gene) and UBT were 20 (42.6\%) while 27 (57.5\%) were positive for UBT and negative for stoolPCR using glmM gene. Table 2 shows the evidenced genes $(\operatorname{cag} \mathrm{A}$ and $g \operatorname{lm} \mathrm{M})$ and the subspecies. The sensitivity and specificity of the $g \operatorname{lm} M$ gene compared with UBT as the gold standard is $42.6 \%$ and $100 \%$ respectively. The positive predictive value (PPV) was $100 \%$ while the negative predictive value (NPV) was $60 \%$.

Figure 1 and 2 shows the PCR amplification of the samples using glmM and $16 \mathrm{~S}$ rRNA genes respectively.

\section{Discussion}

Non-invasive tests can play an important role in the diagnosis of $H$. pylori infections. However, all have their limitations in terms of cost, specificity, and sensitivity. The data presented here, are the results of a pilot study that preceded a project encompassing for UBT and PCR in monitoring a larger dyspeptic patient population. The 16S rRNA PCR amplified Helicobacter DNA (39\%) in stool samples, being the most widely used method for detection of $H$. pylori in clinical specimens. However, the $\operatorname{glm} M$ gene PCR is the most sensitive and specific for the detection of $H$. pylori in gastric biopsy specimens $\mathrm{Lu}$ et al. (1999). The presence of $H$. pylori DNA was found in stool samples (21\%). The results show that to some extent the $\operatorname{glm} M$ gene for detection of $H$. pylori DNA by PCR may be useful for the diagnosis of $H$. pylori from stool. In comparison with UBT as the gold
Table 2 shows cagA + glmM genes with the subspecies, Helicobacter spp. and $H$. pylori

\begin{tabular}{lll}
\hline & Helicobacter spp. (16S rRNA) & H. pylori \\
\hline cagA $+g / m M$ & 8 & 8 \\
glmM & 10 & 12 \\
cagA, glmM - & 20 & - \\
Total & 38 & 20 \\
\hline
\end{tabular}

standard, the sensitivity and specificity was $42.6 \%$ and $100 \%$, respectively. The sensitivity is low. In a related study by Aktepe et al. (2011); using five methods of detection of H. pylori, the stool-PCR had the lowest sensitivity (21\%). However, Makristathis et al. (1998) developed a semi-nested PCR assay, targeted to a species-specific protein antigen which is present in all strains of $H$. pylori, for detection and follow-up of $H$. pylori infected patients and the sensitivity was as high as $93.7 \%$ and the specificity was $100 \%$. Another study by Mishra et al. (2008) corroborated the high sensitivity of stool-PCR in both pre-eradication and post-eradication to be $72.5 \%$ and $97.1 \%$ and the authors concluded that stool-PCR was better indicator than HpSA test in posteradication assessment of infection. Another report by Gramley et al. (1999) reported sensitivity of stool-PCR to be $73 \%$.

In this study, cagA gene was present in $40 \%$ of the samples positive for $H$. pylori by glmM gene and in a related study by Bindayna et al. (2006), cagA gene was found to be present in $22.7 \%$ this is lower than in our study. cagA positive H. pylori strains have been associated with severity of disease outcome and plays a critical role in the development of stomach cancer. From our previous studies with gastric biopsy specimens, cagA positive $H$. pylori was found in $68 \%$ of the biopsy specimens (Smith et al. 2004); while from a related study by Bindayna et al. (2006) 59\% of the biopsy samples were positive for cagA gene, when compared with $22.7 \%$ from stool samples. It goes to show the low prevalence of cagA gene in stool samples when compared to biopsy samples and this could be attributable to low numbers of $H$. pylori in stool samples as well as problems of faecal PCR inhibitors although the Qiagen kit was used to circumvent this in our study. In terms of high sensitivity and specificity found in studies with stool PCR these could be due to methods of DNA extraction as well as

Table 1 Results of stool PCR test using gImM gene with UBT as the gold standard

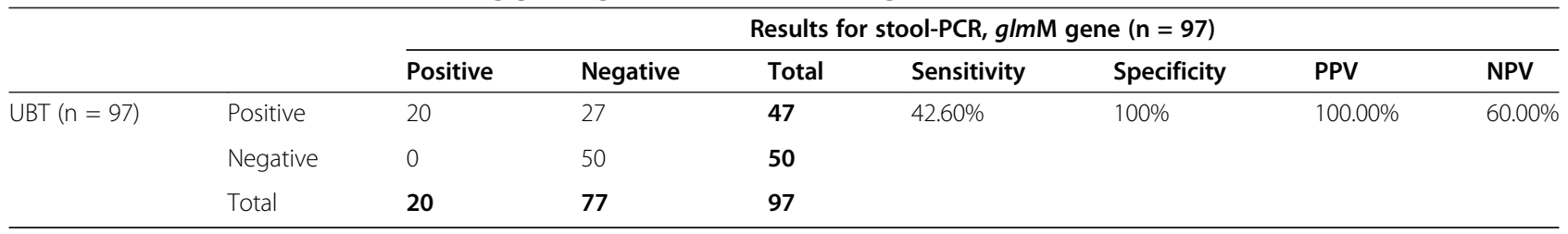




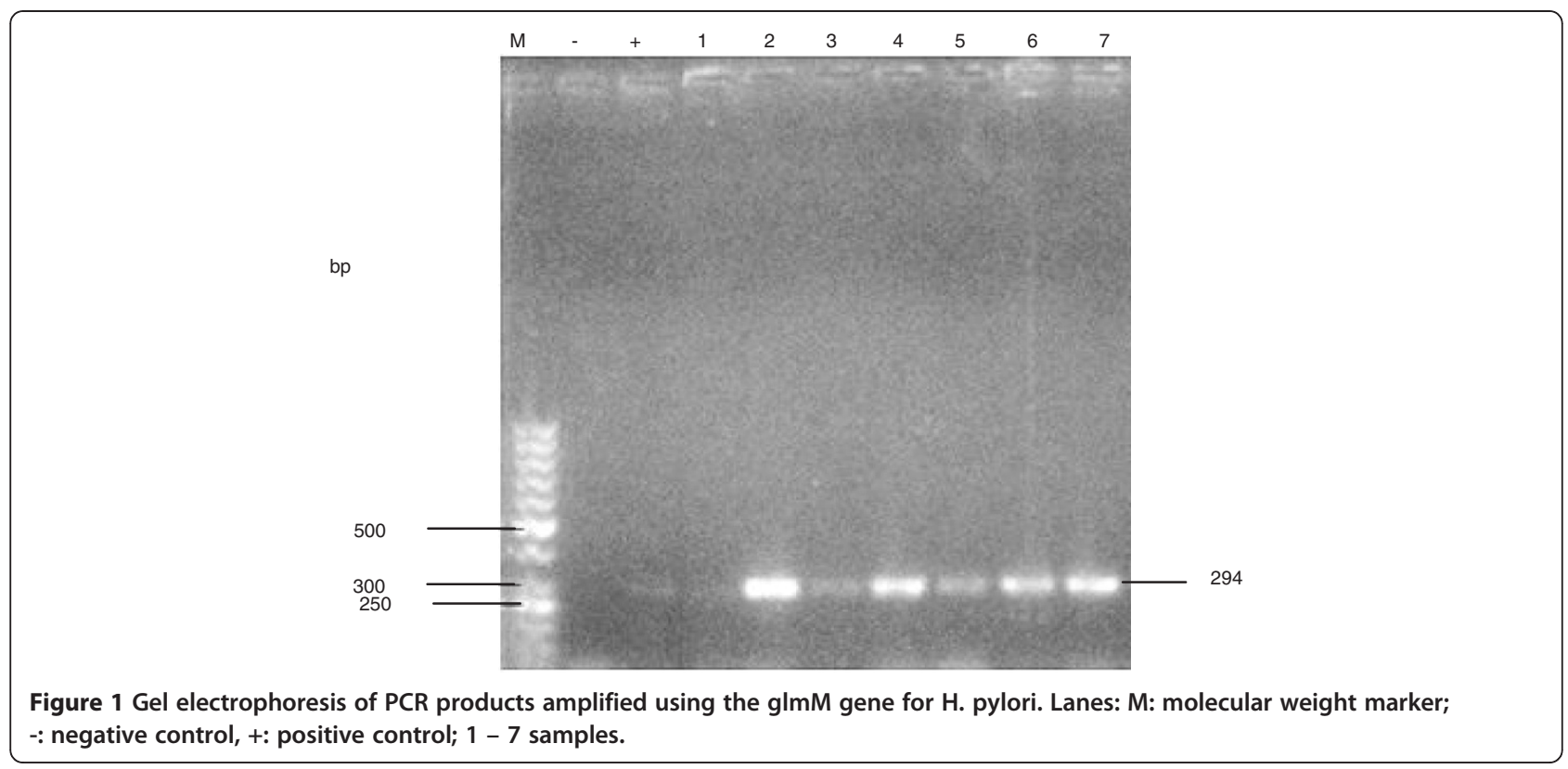

different targets used for detection of $H$. pylori by PCR. In addition, $g \operatorname{lm} M$ and $\operatorname{cag} A$ genes have not been found yet in Helicobacter spp. other than $H$. pylori, suggesting that non-H. pylori helicobacters species may be commonly found in the stool of humans.

The PCR using $H$. pylori species specific primers in the long run could be also useful especially when infants, or very young children and patients with certain neurological disorders are being screened and UBT cannot be convenient for them. The method is also convenient for sample collection and samples can even be collected at home.
The method using the Qiagen stool mini kit is expensive but inexpensive methods that could help remove inhibitors in stool could be used to reduce cost e.g. filteration of stool and column chromatography.

From our study this method is not suitable for routine clinical setting in the developing countries but could be restricted to Reference labs where issues bordering on recurrent $H$. pylori infections and treatment failure are a problem especially where culture is difficult due to power outages in the developing countries. This study did not look at very young children due to the convenient sampling method which was biased.




The advantages and disadvantages of this method in our lab is as follows:

Advantages of stool-PCR

1) It is non-invasive

2) It can be used in children and most especially those with neurological disorders.

3) It is useful for early screening in children to enable prompt detection of $H$. pylori related infection and aid in subsequent treatment.

4) It would capture the generality of children, especially the under 10, as most hospitals don't have child endoscopes so it becomes difficult to screen children thoroughly due to lack of child endoscopes.

\section{Disadvantages}

1) It is expensive for use in developing countries as long as the qiagen kit is employed.

2) It might not be readily available in most diagnostic labs as with other PCR related methods and so has to be restricted to reference labs.

In conclusion, it could be most useful for diagnosis of H. pylori in children especially as endoscope for children is lacking.

\section{Competing interests}

The authors declare that they have no competing interest.

\section{Authors' contributions}

SSI and CM contributed to the idea of the study as well as worked on the manuscript write-up and correction. SSI contributed to part of the molecular studies as well as the sensitivity. FM, AE contributed to the molecular work while LF contributed to the UBT, ACO, contributed to the statistical analysis of PPV and NPV. While everyone contributed to the final draft of the manuscript. All authors read and approved the final manuscript.

\section{Acknowledgement}

Dr. SI Smith would like to acknowledge the support of International Centre for Genetic Engineering and Biotechnology (ICGEB) grant number NIG-07 for the work carried out.

\section{Author details}

${ }^{1}$ Molecular Biology and Biotechnology Division, Nigerian Institute of Medical Research, 6 Edmond Crescent, Yaba, PMB 2013, Lagos, Nigeria. ²Department of Medicine, College of Medicine, University of Lagos, Lagos, Nigeria. ${ }^{3}$ Department of Cell Biology and Genetics, University of Lagos, Lagos, Nigeria. ${ }^{4}$ Department of Pathology, College of Medicine, University of Lagos, Lagos, Nigeria. ${ }^{5}$ Department of Medicine, Lagos State University Teaching Hospital (LASUTH), Ikeja, Nigeria. ${ }^{6}$ Biochemistry and Nutrition Division, Nigerian Institute of Medical Research, 6 Edmond Crescent, Yaba, Lagos, Nigeria. ${ }^{7}$ Instituto Venezolano de Investigaciones Científicas, Caracas, Venezuela.

Received: 15 October 2012 Accepted: 13 December 2012 Published: 22 December 2012

\section{References}

Aktepe OC, Ciftci IH, Safak B, Uslan I, Dilek FH (2011) Five methods for the detection of Helicobacter pylori in the Turkish population. World J Gastroenterol 17:5172-5176
Bindayna KM, Al Baker WA, Botta GA (2006) Detection of Helicobacter pylori cagA gene in gastric biopsies, clinical isolates and faeces. Indian J Med Microbiol 24:195-200

Blaser MJ, Berg DE (2001) Helicobacter pylori genetic diversity and risk of human disease. J Clin Invest 107:767-773

Covacci A, Telford JL, Del Giudice G, Parsonnet J, Rappuoli R (1999) Helicobacter pylori virulence and genetic geography. Science 284:1328-1333

Germani Y, Dauga C, Duval P et al (1997) Strategy for the detection of Helicobacter species by amplification of 165 rRNA genes and identification of H. felis in a human gastric biopsy. Res Microbiol 148:315-326

Gramley WA, Ashgar A, Frierson HF, Powell SM (1999) Detection of Helicobacter pylori DNA in faecal samples from infected individuals. J Clin Microbiol 37:2236-2240

Hirai I, Sasaki T, Kimoto A, Fujimoto S, Moriyama T, Yamamoto Y (2009) Assessment of East-Asian type cagA positive Helicobacter pylori using stool specimens from asymptomatic healthy Japanese individuals. J Med Microbiol 58:1149-1153

International Agency for Research on Cancer (IARC) Monogr Eval Carcinog Risks Hum (1994) Schistosomes, liver flukes and Helicobacter pylori. IARC Working Group on the Evaluation of Carcinogenic Risks to Humans, Lyon, 7-14 June $1994.61: 1-241$

Kabir S (2001) Detection of Helicobacter pylori in faeces by culture, PCR and enzyme immunoassay. J Med Microbiol 50:1021-1029

Kansau I, Raymond J, Bingen E et al (1996) Genotyping of Helicobacter pylori isolates by sequencing of PCR products and comparison with the RAPD technique. Res Microbiol 147:661-669

Lu JJ, Perng CL, Shyu RY et al (1999) Comparison of five PCR methods for detection of Helicobacter pylori DNA in gastric tissues. J Clin Microbiol 37:772-774

Makristathis A, Pasching E, Schutze K, Wimmer M, Rotter ML, Hirschl AM (1998) Detection of Helicobacter pylori in stool specimens by PCR and antigen enzyme immunoassay. J Clin Microbiol 36:2772-2774

Mégraud F, Lehours P (2007) Helicobacter pylori detection and antimicrobial susceptibility testing. Clin Microbiol Rev 20:280-322

Mishra S, Singh V, Rao G et al (2008) Detection of Helicobacter pylori in stool specimens: comparative evaluation of nested PCR and antigen detection. Infect Genet Evol 8:815-819

Rugge M, Busatto G, Cassaro M et al (1999) Patients younger than 40 years with gastric carcinoma: Helicobacter pylori genotype and associated gastritis phenotype. Cancer 85:2506-2511

Şen N, Yilmaz Ö, Sıımşek I, Küpelıoğlu AA, Ellıdokuz H (2005) Detection of Helicobacter pylori DNA by a Simple Stool PCR Method in Adult Dyspeptic Patients. Helicobacter 10:353-359. doi:10.1111/j.1523-5378.2005.00326.x

Smith SI, Oyedeji KS, Arigbabu AO et al (2004) Comparison of three PCR methods and cagA for the detection of $H$. pylori DNA from gastric biopsies. World J Gastroenterol 10:1958-1960

doi:10.1186/2193-1801-1-78

Cite this article as: Smith et al: Application of stool-PCR for the diagnosis of Helicobacter pylori from stool in Nigeria- a pilot study. SpringerPlus 2012 1:78.

\section{Submit your manuscript to a SpringerOpen ${ }^{\odot}$ journal and benefit from:}

- Convenient online submission

Rigorous peer review

- Immediate publication on acceptance

- Open access: articles freely available online

- High visibility within the field

- Retaining the copyright to your article

Submit your next manuscript at $>$ springeropen.com 